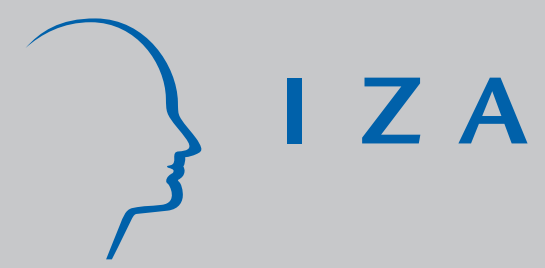

IZA DP No. 7138

'Make-or-Buy' of Peripheral Services in Manufacturing: Evidence from Spanish Plant-Level Data

Alberto Bayo-Moriones

Jose Enrique Galdón-Sánchez

Ricard Gil

January 2013

Forschungsinstitut zur Zukunft der Arbeit Institute for the Study of Labor 


\title{
'Make-or-Buy' of Peripheral Services in Manufacturing: Evidence from Spanish Plant-Level Data
}

\author{
Alberto Bayo-Moriones \\ Universidad Pública de Navarra \\ Jose Enrique Galdón-Sánchez \\ Universidad Pública de Navarra \\ and IZA \\ Ricard Gil \\ Johns Hopkins Carey Business School
}

Discussion Paper No. 7138

January 2013

IZA

P.O. Box 7240

53072 Bonn

Germany

Phone: +49-228-3894-0

Fax: +49-228-3894-180

E-mail: iza@iza.org

Any opinions expressed here are those of the author(s) and not those of IZA. Research published in this series may include views on policy, but the institute itself takes no institutional policy positions. The IZA research network is committed to the IZA Guiding Principles of Research Integrity.

The Institute for the Study of Labor (IZA) in Bonn is a local and virtual international research center and a place of communication between science, politics and business. IZA is an independent nonprofit organization supported by Deutsche Post Foundation. The center is associated with the University of Bonn and offers a stimulating research environment through its international network, workshops and conferences, data service, project support, research visits and doctoral program. IZA engages in (i) original and internationally competitive research in all fields of labor economics, (ii) development of policy concepts, and (iii) dissemination of research results and concepts to the interested public.

IZA Discussion Papers often represent preliminary work and are circulated to encourage discussion. Citation of such a paper should account for its provisional character. A revised version may be available directly from the author. 


\section{ABSTRACT \\ 'Make-or-Buy' of Peripheral Services in Manufacturing: Evidence from Spanish Plant-Level Data*}

In this paper we empirically explore the 'make-or-buy' decisions of peripheral services in manufacturing plants using detailed information on a data set from a new plant-level survey from 926 plants distributed in all manufacturing industries in Spain. In particular, survey respondents are asked how their contracting practices of peripheral services had changed in the last three years. The answer to this question is informative of the changes in the importance of backward integration for each of the plants interviewed. Using other information provided in the survey, we relate reported changes in backward integration to changes in other relevant plant characteristics. We show that increases in outsourcing of services are positively correlated with increases in the plant's market share as well as increases in product market competition and product prices. These findings are robust to controlling for whether plants belong to single-plant or multi-plant firms. This result is consistent with the view that market size limits the degree of specialization at the plant level in the Spanish manufacturing industry.

JEL Classification: L23, L22, L60

Keywords: make-or-buy, peripheral services, manufacturing, market share, competition

Corresponding author:

Jose Enrique Galdón-Sánchez

Universidad Publica de Navarra

Departamento de Economía

Campus de Arrosadía

31006 Pamplona

Spain

E-mail: jose.galdon@unavarra.es

\footnotetext{
* We would like to thank César Alonso for very helpful comments and suggestions. We also thank Sara Martínez de Morentín for valuable research assistance. We thank the Fundación BBVA for providing us with funding to conduct the survey on the Spanish establishments. The first and second authors acknowledge financial support from Ministerio de Educación y Ciencia project SEJ2007-66511 and Ministerio de Economía y Competitividad project ECO2011-24304, respectively.
} 


\section{Introduction}

Simple observation and empirical evidence over the years have shown that firms and organizations display a wide variety of ways to organize their production. This fact remains a puzzle for economists since most theoretical approaches cannot explain why we observe different organizational forms taking place in the same industry. ${ }^{1}$ Therefore, understanding the organization of production within and across industries as well as within and across firms' boundaries is a central question in economics.

The study of the organization of production began with Adam Smith and his study of the organization of labor in pin factories and was only followed much later by Coase (1937) and then followed by others in transaction costs economics (Williamson, 1975) and property rights (Grossman and Hart, 1986) theories. ${ }^{2}$ Despite these various theories, empirical evidence on vertical integration and outsourcing has yet to provide a clear idea of what theories explain 'make-or-buy' decisions better (see Lafontaine and Slade, 2007, or Macher and Richman, 2008, for recent literature reviews). Even though early papers by Masten (1984) and Monteverde and Teece (1982) support predictions of transaction cost economics, these and other more recent papers say little about property rights (see Whinston, 2003) and other sets of theories. ${ }^{3}$ In fact, Lafontaine and Slade (2007) emphasize in their recent survey of this literature that more papers in this area are necessary to gain understanding of how the different existing theories and their different organizational trade-offs are relevant for the striking variety of outsourcing patterns observed across industries.

Our paper contributes to the empirical literature from a different angle than those papers mentioned above. On the one hand, our paper brings evidence on robust patterns across different manufacturing industries. Evidence across industries is scarce as most papers in

\footnotetext{
${ }^{1}$ Legros and Newman (2008) and Gibbons, Holden and Powell (2011) are recent exceptions where different organizational forms may coexist in a market in equilibrium. Antras and Helpman (2004) is representative of models obtaining heterogeneity in outcomes departing from heterogeneity in firms costs. ${ }^{2}$ Others emphasized the role of asset ownership and vertical integration on incentive provision (Holmstrom and Milgrom (1991)) or its importance for ex-post adjustment (Simon (1951)). Gibbons (2005) provides a summary of all four types of theories and how others may relate to them.

${ }^{3}$ For example, Woodruff (2002) tests implications of property right theories, Baker and Hubbard (2003) tests incentive based theories and Forbes and Lederman (2009) theories on ex-post adjustment. Akerman and Py (2011) tests Stigler's hypothesis of market size limiting the scope of specialization and vertical integration.
} 
this literature are industry specific with an important emphasis on institutional detail. On this note, Hortacsu and Syverson (2009) and Acemoglu et al. (2006) are two examples that explore patterns on vertical integration across industries and years in the US and UK respectively. Our paper mainly differs from theirs in that our data comes from a selfcollected questionnaire-based data set from a sample of Spanish manufacturing plants and that our focus is on vertical integration of low-value services that are peripheral to the core activity in these manufacturing plants and yet important to the delivery of the final product. These outsourced services are for example maintenance, computing, logistics and clerical services among others.

Outsourcing decisions of this type have been studied in international trade and productivity (Griliches and Siegel (1992)) as well as labor economics (Abraham and Taylor (1996), but barely ever in industrial organization since the literature has mainly focused on inputs for production, and only marginally in strategy and business economics (see Tiwana and Keil, 2007, and Ren and Zhou, 2008, for examples in the management literature). Given the scarcity of available evidence, we believe our paper represents an important contribution to the understanding of outsourcing decisions of peripheral and yet essential activities within and across establishments, firms and industries. If anything, the closest paper to ours is Merino and Rodriguez (2007) that tests the implications in Grossman and Helpman (2002) using a cross-sectional data set on outsourcing decisions of peripheral services in Spanish manufacturing plants. Ours differs from theirs in that we examine within plant variation in service outsourcing, but we cannot separate what services are actually being outsourced.

In particular, here we investigate the determinants of changes in outsourcing of services as an exercise that uncovers empirical correlations between changes in plants' levels of outsourcing of services and other changes in the plants' competitive environment. We hope that this resulting empirical evidence sheds light on potential determinants of outsourcing practices. Therefore our contribution is mainly on the empirical side and, if anything, we hope to foster further theoretical research that may provide sound explanations for the patterns in outsourcing that we (and others) find in our data set. 
We present a new data set on manufacturing plants ${ }^{4}$ in Spain. This unique data set is comprised of direct information on several plants' practices for 926 industrial establishments in Spain. The data set has its origin on a survey conducted in 2006 and contains information for a total of 1001 plants for which only 926 provide information on how their outsourcing practices changed between 2003 and 2006. All surveyed establishments are involved in production processes within the manufacturing sector. The questionnaire provides valuable information regarding backward integration and outsourcing practices of services. Overall, we obtain very homogeneous data for every surveyed plant. At the same time, the survey contains a wide scope of different establishments within the manufacturing sector.

Since the variables of interest in this data set, and relevant to our study, are informing us of changes occurred in outsourcing of services within a plant (as well as changes in other plant dimensions) in the last three years, we take these as proxy variables for the direction of change and the sign of the variable first differences. We then empirically examine how changes in outsourcing correlate with changes in the plants' competitive environment dimensions such as changes in competition, product prices, market share, number of employees, production cost or product quality. Our original variable is in Likert scale values from 1 to 5 denoting strong decreases with value of 1 and strong increases in outsourcing as 5 passing through 3 as no significant changes occurred. We also create a variable that indicates the sign of change as $-1,0$ and +1 for any decrease, no change and any increase respectively. Finally, we create indicator variables for whether the plant experienced an increase in outsourcing as well as any of the potential determinants of outsourcing at the plant level. We proceed to run linear probability OLS regressions as well as ordered logit regressions taking advantage of the ordered nature of the dependent variable.

Our main findings show that increases in market share and increases in product market competition are positively correlated with increases in outsourcing. We also find some evidence that increases in prices or production costs are associated with increases in

\footnotetext{
${ }^{4}$ Here, we use the terms plant, establishment and manufacturing factory interchangeably.
} 
outsourcing of services. These findings are robust to the inclusion of industry fixed effects as well as to using different specifications.

We investigate further the robustness of these results and consider whether independent plants (plants that are their own firm) and plants belonging to multi-plant firms react differently to the changes in our explanatory variables. We find that these two types react with different intensity to changes in market share but yet in the same direction. In particular, we find that multi-plant firms are more likely to increase outsourcing when their market share and product price increases. These plants are also more likely to experience a decrease in the number of employees when their outsourcing of services increases. This subtle difference in behavior is informative of how different plants can reorganize their production and outsourcing practices. While multi-plant firms are more likely to change their organization of production when facing changes in their competitive environment by reshuffling resources across different plants within their own firm, single-plant firms are more likely to "ignore" those changes in their competitive environment.

Finally, we conduct several robustness checks that deal with biases due to variable omission or differences in baseline outsourcing rates. We include other regressors that proxy for differences in outsourcing costs and preferences that may vary across plants and therefore may be correlated with the error term in ways that our main specifications are not capturing. Our results are also robust to these final robustness checks.

The paper is organized as follows. After this introduction, we describe the data that we use for this study in section 2. Section 3 presents our methodology. Next, we show our results and the robustness checks that we undertake in section 4 . In that section, we also offer a discussion of how our findings relate to previous results in the empirical literature and potential implications for the existing theoretical literature. Section 5 concludes.

\section{Data Description}

In this section we describe the data source, how the data were collected and the variables that we use in our empirical exercise. We will start by describing the questionnaire from 
which we obtained the data set and then proceed to describe the variables used in our analysis.

\subsection{The questionnaire}

Our analysis is based on data from a Spanish data set collected in 2006 as part of a survey on firms' employment and work practices in the Spanish manufacturing industry. ${ }^{5}$ Information was collected at the establishment level. Establishments are unique locations where economic activity takes place. In our case, and for the manufacturing industry, those locations are manufacturing factories. The data was gathered through personal interviews with managers in those manufacturing factories with fifty or more employees, and represents a unique source of information about diverse management practices in Spain. The project was intended to be a partial continuation of a previous study carried out in 1997.

The main reason to undertake the analysis at the establishment level, and not at the firm level, is that the establishment is the unit at which decisions about the implementation of the practices of interest are taken. Furthermore, we expected the knowledge of the issues and questions included in the questionnaire to be greater at plant level and, as a consequence, the information gathered to be more reliable. This idea was corroborated in the pre-test and confirmed, afterwards, during the development of the survey.

Once defined the objectives and scope of our study, and in order to properly design the questionnaire, we carried out a thorough examination of the literature related to the purpose of the project. With this information gathered, a first draft of the questionnaire was drawn up jointly by the members of the research group and the company in charge of the fieldwork. The questionnaire was pre-tested in nine plants. The pretest confirmed that the wording of the questions was precise and easy to understand by the respondents since no problems emerged during this part of the design process.

This final version of the questionnaire consists of 152 questions grouped in the following eight sections: General Characteristics of the Plant and the Firm, Human Resources,

\footnotetext{
${ }^{5}$ These same data is also used in Bayo-Moriones, Galdon-Sanchez and Martinez-de-Morentin (2013) where a more extensive description of the data can be found.
} 
Payment Systems, Work Organization, Human Resource Outcomes, Human Resource Function, Other Groups of Workers and Characteristics of the Plant Manager.

The data was drawn from personal interviews with the general manager of the plant. The universe of potential respondents for the purposes of the project was constituted for all Spanish manufacturing establishments with fifty or more employees in 2005, which amounts to 6971 units. ${ }^{6}$ The aim was to obtain a sample of one thousand units, in order to get conclusions that could be extended to the entire Spanish manufacturing industry. After stratification by sector, size and location, a random selection of workplaces was obtained from the 2005 Spanish Central Directory of Firms (Directorio Central de Empresas, DIRCE) of the Spanish National Statistics Institute (Instituto Nacional de Estadística, INE). Finally, 1002 establishments were interviewed, what represents $14.38 \%$ of the total target population. The response rate was $25.44 \%$.

The interviews with those managers that agreed to answer our questionnaire were performed by specially trained professionals using computer assisted telephone interviews (CATI). The establishments were first approached by a letter or an email indicating the goals of the survey and including a copy of the questionnaire.

\subsection{The variables}

In what follows, we describe the variables used in our empirical analysis. We chose these variables mainly because of availability and prediction power according to well established theories of vertical integration (price, production cost, plant size, market share, competition and technology). The questionnaire provides information on the factors that influence outsourcing practices of services, that is, backward vertical integration of peripheral services to the core manufacturing activities and yet necessary for plant production. We obtain the information on those factors from the answers given in the questionnaire to a block question.

\footnotetext{
${ }^{6}$ See Tables A1 and A2 in Appendix 1 for representativeness of our sample relative to the population of manufacturing plants in Spain with 50 or more employees. Even though manufacturing plants with 50 or more employees represent only $1 \%$ of all establishments in the manufacturing industry, these give employment to slightly more than $50 \%$ of employment in manufacturing and are responsible for $75 \%$ of all gross value added generated in this industry.
} 
In that question, the establishments are asked about the evolution of several aspects related to the plant in the three years previous to the survey. ${ }^{7}$ The seven aspects considered are the following (the name of the corresponding variable appears in parenthesis): the change in the outsourcing carried out by the plant (change in service outsourcing), the change in the number of employees at the plant (change in \# employees), the change in the plant's production cost (change in production cost), the change in the plant's product quality (change in product quality), the change in the plant's product price (change in product price), the change in competition in the main sector where the plant develops its activity (change in competition) and the change in the market share of the plant (change in market share). For each one of these questions, the establishments were given five different options ranging from a large reduction (1) to a large increase (5) in the aspect being evaluated. We use the information provided in the questionnaire to recode the Likert scale measure into a variable that captures the sign of change by assigning value 1 if there is an increase (values 5 and 4 in the original answer), value 0 if there is no change (value 3 in the original answer) and value -1 if there is a decrease (values 1 and 2 in the original answer). We used this criterion mainly because most observations in the original answer took values 2, 3 and 4 and therefore relying only on the extreme values 1 and 5 would have left us with almost no variation. Finally, we also code a third measure as a dummy variable that takes value 1 if there was an increase and 0 otherwise. The sample means, standard deviations and definitions of these three types of variables are presented in Tables $1 \mathrm{~A}^{8}$

\section{[Table 1A here]}

Let us now describe the summary statistics in Table 1A. In this table, we provide summary statistics of the three sets of measures of changes described above. First, let us concentrate on the Likert scale measures. See that all averages are above 3 which means that on average all measures increased in the previous years. Second, we have the sign of

\footnotetext{
${ }^{7}$ See Appendix B for the original question in Spanish and a self-made translation to English.

${ }^{8}$ See that, even though 1002 plants were interviewed, only 926 of those responded to the question whether changes in outsourcing of services had occurred in the previous three years.
} 
change measures with values $-1,0$ and +1 that show averages well above 0 consistently with the summary statistics of the Likert scale measures. Finally, we present summary statistics for indicator variables that take value 1 if there was an increase in the variable and 0 otherwise. As these are easier to interpret than the two previous sets of variables, we comment on these more extensively. According to Table 1A, 38\% of the plants increased their outsourcing of services, $43 \%$ increased their number of employees, $63 \%$ increased the amount of technology, and $48 \%$ of the plants belong to multi-plant firms. Note that for some of the remaining variables used in our empirical analysis, we do not have information for the full sample. Of these other variables, we can see that $69 \%$ increased their production costs, 69\% increased their product quality, 59\% increased their product price, $63 \%$ saw their product market competition increase, and $48 \%$ increased their market share.

Table 1A also provides information on changes in technology. In our survey, the establishments are asked about the technical change implemented by the plant in the three years previous to the survey, if any. To answer that question, they were given five different options ranging from a total change to no change at all. From the answers gathered to that question we construct our variable in the following way: we assign value 1 if there has been substantial change in technology (values 5, 4 and 3 in the original answer), value 0 if there has been slight change or no change (values 1 and 2 in the original answer). According to the latter, we find out that only $27 \%$ of the plants undertook significant changes in technology during the previous three years.

Finally, Table 1A separates plants in our sample between independent and integrated plants and tests for differences between these two groups. We find statistically significant differences in changes in the number of employees, product costs, product prices and technology. There are no apparent differences in changes in outsourcing practices, competition or market shares according to the evidence in Table 1A. ${ }^{9}$

\footnotetext{
${ }^{9}$ To establish the credibility of the survey responses, we build the correlation matrix for the dependent and main independent variables (not shown here but available upon request). It is reassuring that increases in market share are negatively correlated with increases in competition, which is negatively correlated with increases in price. Similarly, changes in technology are negatively correlated with changes in cost. Available also upon request, we built a Spearman rank correlation matrix.
} 
In Table $1 \mathrm{~B}$ we offer summary statistics of variables that we use as controls in our empirical analysis and in some of our robustness checks. These differ from those in Table $1 \mathrm{~A}$ in that these are variables in levels and do not provide information on changes occurred between 2003 and 2006. On average, the plants in our sample had 190 employees and were first built up in 1969. Of all the plants in our sample $47 \%$ of them are integrated into a larger organization structure and their labor cost represent $31 \%$ of their total cost of production. They also count with $7 \%$ of their workers as college graduates and $34 \%$ of them have a high school degree. Finally, 5\% of the plants outsourced recruiting of manufacturing workers and laid off on average 15\% of their workers due to retirement and 5\% due to other reasons. Finally, in terms of asking their workers to repair and maintain their machines on average they asked them to do so with 6 and 4 in a scale of 10 respectively.

Table 1B also breaks the summary statistics between independent and integrated plants and we observe that independent plants are smaller, less likely to outsource recruiting, less likely to fire workers due to retirement or other reasons and less likely to have college graduates among their workers. Instead they are more likely to ask their workers to maintain their machines. There is no statistical difference in all other variables.

[Table 1B here]

Table 2 breaks down in our sample the dependent variable 'Change in Outsourcing' by industry. This table shows the number of plants in each industry within our sample and the percentage of plants within each industry that decreased outsourcing of services, the percentage that did not experience any changes and the percentage of those that increased outsourcing of services. In absolute numbers, a total of 105 out of the 926 plants decreased outsourcing, 467 did not change their outsourcing practices and the remaining 354 increased outsourcing. Most industries follow the same pattern, except for "Mechanical Equipment," "Electrical Equipment" and "Transportation Equipment." These three differ from the others in that they have more plants increasing outsourcing than experiencing no change. All other industries are similar otherwise. 
[Table 2 here]

\section{Empirical Methodology}

The traditional empirical approach in the literature of the determinants of organizational form runs a simple OLS regression using cross-sectional data ${ }^{10}$ such that,

$$
\mathrm{Y}^{*}{ }_{\mathrm{it}}=\alpha+\beta \mathrm{X}^{*}{ }_{\mathrm{it}}+\mathrm{u}_{\mathrm{it}}
$$

where $\mathrm{Y}^{*}{ }_{\text {it }}$ is an indicator variable for the extent to which a firm $\mathrm{i}$ uses a determinate organizational form, $\mathrm{X}^{*}{ }_{\mathrm{it}}$ is a control variable that includes various determinants of organizational form and $\mathrm{u}_{\mathrm{it}}$ is an identically and independently random draw from a normal distribution. Our data does not allow us to perform this type of analysis because we do not observe the amount of outsourcing in each plant. Instead, we only observe whether the amount of outsourcing increased, decreased or stayed the same.

For this reason, we transition from equation (1) to a first-differences empirical regression such that

$$
\Delta \mathrm{Y}^{*}{ }_{\mathrm{it}}=\beta \Delta \mathrm{X}^{*}{ }_{\mathrm{it}}+\Delta \mathrm{u}_{\mathrm{it}}
$$

where $\Delta \mathrm{Y}^{*}{ }_{\mathrm{it}}$ and $\Delta \mathrm{X}^{*}{ }_{\mathrm{it}}$ are first differences of variables $\mathrm{Y}^{*}{ }_{\mathrm{it}}$ and $\mathrm{X}^{*}{ }_{\mathrm{it}}$, and $\Delta \mathrm{u}_{\mathrm{it}}=\mathrm{u}_{\mathrm{it}}-\mathrm{u}_{\mathrm{it}-1}$. Unfortunately, we cannot directly observe these either since our variables $\Delta \mathrm{Y}^{*}$ it and $\Delta \mathrm{X}^{*}{ }_{\text {it }}$ are latent variables coded as Likert scales that provide information for whether $\Delta \mathrm{Y}^{*}{ }_{\mathrm{it}}>\Delta \mathrm{Y}^{*}{ }_{\mathrm{jt}}>0, \Delta \mathrm{Y}^{*}{ }_{\mathrm{it}}=0$, or $\Delta \mathrm{Y}^{*}{ }_{\mathrm{it}}<\Delta \mathrm{Y}^{*}{ }_{\mathrm{jt}}<0$ (the same goes for $\Delta \mathrm{X}^{*}{ }_{\mathrm{it}}$ ). For this reason, we create variables $\Delta \mathrm{Y}_{\text {it }}$ and $\Delta \mathrm{X}_{\mathrm{it}}$ such that $\Delta \mathrm{Y}_{\mathrm{it}}=+1$ if $\Delta \mathrm{Y}^{*}{ }_{\text {it }}>0, \Delta \mathrm{Y}_{\mathrm{it}}=0$ if

\footnotetext{
${ }^{10}$ Papers using cross-sectional data in organizational economics are Monteverde and Teece (1982) or Masten (1984), or more recently Gil (2007) and Forbes and Lederman (2009). Abraham and Taylor (1996) and Merino and Rodriguez (2007) also use cross-sectional variation to examine 'make-or-buy' decisions of peripheral services in manufacturing plants.
} 
$\Delta \mathrm{Y}^{*}{ }_{\mathrm{it}}=0$, and $\Delta \mathrm{Y}_{\mathrm{it}}=-1$ if $\Delta \mathrm{Y}^{*}{ }_{\mathrm{it}}<0$ (same rule would apply to $\Delta \mathrm{X}_{\mathrm{it}}$ and $\Delta \mathrm{X}^{*}{ }_{\mathrm{it}}$ ). Finally, we also transform our variables into dummy variables $\mathrm{D}\left[\Delta \mathrm{Y}_{\mathrm{it}}=+1\right]$ (and $\mathrm{D}\left[\Delta \mathrm{X}_{\mathrm{it}}=+1\right]$ ) that take value 1 if $\Delta \mathrm{Y}^{*}{ }_{\mathrm{it}}>0\left(\right.$ or $\left.\Delta \mathrm{X}^{*}{ }_{\mathrm{it}}>0\right)$ and 0 otherwise.

In our empirical analysis, we run three types of regressions. The first is a set of simple OLS regression analysis taking the following regressions equation as basis,

$$
\begin{gathered}
\Delta \mathrm{Y}^{*}{ }_{\mathrm{it}}=\beta \Delta \mathrm{X}^{*}{ }_{\mathrm{it}}+\Delta \mathrm{u}_{\mathrm{it}} \\
\Delta \mathrm{Y}_{\mathrm{it}}=\beta \Delta \mathrm{X}_{\mathrm{it}}+\Delta \mathrm{u}_{\mathrm{it}} \\
\mathrm{D}\left[\Delta \mathrm{Y}_{\mathrm{it}}=+1\right]=\alpha+\beta \mathrm{D}\left[\Delta \mathrm{X}_{\mathrm{it}}=+1\right]+\Delta \mathrm{u}_{\mathrm{it}}
\end{gathered}
$$

This first set of specifications is just uncovering raw correlations between our measures of changes in outsourcing and our right-hand side variables. In the second type of analysis, we take full advantage of the ranking-type form of our data and realize that if $\Delta \mathrm{Y}_{\mathrm{it}}>\Delta \mathrm{Y}_{\mathrm{jt}}$, it must also be true that $\Delta \mathrm{Y}^{*}{ }_{\mathrm{it}}>\Delta \mathrm{Y}^{*}{ }_{\mathrm{jt}}$ and therefore,

$$
\beta \mathrm{D}\left[\Delta \mathrm{X}_{\mathrm{it}}=+1\right]+\Delta \mathrm{u}_{\mathrm{it}}>\beta \mathrm{D}\left[\Delta \mathrm{X}_{\mathrm{jt}}=+1\right]+\Delta \mathrm{u}_{\mathrm{jt}}
$$

For this purpose, we run ordered logit regressions such that,

$$
\operatorname{Prob}\left[\Delta \mathrm{Y}_{\mathrm{it}}>\Delta \mathrm{Y}_{\mathrm{jt}}\right]=\operatorname{Prob}\left[\beta\left(\mathrm{D}\left[\Delta \mathrm{X}_{\mathrm{it}}=+1\right]-\mathrm{D}\left[\Delta \mathrm{X}_{\mathrm{jt}}=+1\right]\right)>\Delta \mathrm{u}_{\mathrm{jt}}-\Delta \mathrm{u}_{\mathrm{it}}\right]
$$

Along all specifications, we also introduce fixed effects at the industry level such that the determinants of changes in outsourcing practices are identified from variation within an industry and not out of industry-specific shocks common to all plants in a particular industry. Nevertheless, we anticipate that different plants within an industry may face different shocks or may react differently to these same shocks. In order to control for this underlying heterogeneity, we introduce all variables available to us in our data set that 
vary at the plant level and may be correlated with plant-level shocks that drive outsourcing decisions. We show our results in the next section keeping in mind that, eventually, we are posting an empirical question and therefore we are aiming to unravel which factors are correlated with observed changes in outsourcing practices in our sample.

\section{Results}

In this section we show our results in two main bulks of evidence. The first part directly addresses the question of what are the potential determinants of the changes in service outsourcing. The second part explores alternative explanations and robustness checks. We close this section with a discussion of the results.

\subsection{Initial Set of Results}

We develop our first set of results in Table 3. We start by running the regression specifications in (3) in the methodology section. This table shows correlation coefficients between the three sets of measures of changes in outsourcing practices and their corresponding measures of changes in the number of employees, cost, price, quality, competition, market share and technology as well as a dummy variable that takes value 1 if the plant belongs to a multi-plant firm and 0 otherwise.

Columns (1) to (4) run OLS regressions with our Likert scale measures. These specifications vary by the use of the change in technology variable and the inclusion of industry fixed effects. In the end, all four specifications offer similar results as they show that increases in outsourcing of services are positively correlated with increases in product price, increases in competition and increases in market share. In columns (6) and (7) we repeat the analysis replacing our Likert scale measures by measures of sign of change $(-1,0$ or +1$)$ for both left-hand side and right-hand side variables. These specifications offer results very similar qualitatively speaking as we report very strong and statistically significant positive correlations between changes in outsourcing and 
changes in market share. These two specifications also show statistically significant correlations between outsourcing and product cost and prices.

Finally, the last two specifications in Table 3 report results of running linear probability regressions of dummy variables that take value 1 if the variable increased, and 0 otherwise. The results in these two specifications offer very similar results to those of columns (1) to (4) as they show statistically significant positive correlations between increases in outsourcing and increases in product prices, competition and market share. The dummy variable for whether the plant belongs to a multi-plant firm lacks statistical significance across all specifications in Table 3.

[Table 3 here]

In addition to OLS specifications, columns (5) and (8) also provide results from orderedlogit regressions that provide identical results with statistically significant positive coefficients on changes in production costs, competition and market share. These are robust to the definition of the dependent variable (Likert scale or sign of change definition). Given that coefficients in ordered logit show effect on the latent variable of outsourcing, our results from column (8) show that plants that see their market share increase see an average increase of 0.71 points in service outsourcing. Similarly plants that face an increase in competition also increase service outsourcing by 0.22 base points relative to plants that do not increase their market share nor face increasing competition.

\subsection{Single-Plant versus Multi-Plant Firms}

We also run similar specifications differentiating plants that belong to multi-plant firms and those that are single-plant firms. The changes in outsourcing practices that take place in either of these types may be very different even when the changes in outsourcing are the same. Plants belonging to multi-plant firms may be experiencing a reorganization of services and tasks across plants within the firm, whereas single-plant firms reorganize activities across firm boundaries. 
Therefore we examine whether outsourcing practices of services in these two types of plants react differently to changes in the plant's competitive environment. First, Table 3 shows that multi-plant firms are equally likely to change their outsourcing practices. Second, we explore in Table 4 whether integrated plants react more strongly to changes in their competitive environment than independent plants. We do this by repeating the analysis in Table 3 including interaction variables between the 'Multi-Plant Firm?' dummy and all other right-hand side variables. Statistically significant coefficients in these interacted variables denote that multi-plant firms react differently to changes in right-hand side variables.

Results in Table 4 show that changes in service outsourcing practices in multi-plant firms respond more abruptly to changes in product prices and changes in market share than single-plant firms. We find no differences across types of plants in the correlation between changes in outsourcing of services and changes in competition.

[Table 4 here]

Another potential problem in our analysis so far may be that of omission bias. If this is a problem, even after including industry fixed effects, the error term may still be correlated with our explanatory variables. To address this issue, we use all relevant variables that are available in our data set and that describe dimensions of the plants that a priori may be correlated with differences in levels of outsourcing of services adopted by the plants. Therefore columns (1), (2), (7) and (8) of Table 5 include variables such as the percentage of labor costs for the plant, the average number of employees during 2005, the year in which the plant started functioning as a proxy for the age of the plant and the percentage of workers with college and high school degrees to attenuate the omission variable bias. The inclusion of these variables has no impact on the initial results. As a matter of fact, only the percentage of workers with a college degree seems to be positively correlated with changes in outsourcing of services. 
[Table 5 here]

\subsection{Other Robustness Checks: Baseline Outsourcing Levels}

Our final robustness check has to do with the fact that we do not have information on the baseline outsourcing levels of each one of the plants in our sample. To address this issue, we first turn to creative econometric methodology and second we use a number of variables that are likely to proxy for the proclivity of a plant to outsource its services.

Let us depart from the regression specification (3) in the methodology section above and note that outsourcing baseline levels should not be a concern since all level information is wiped out when using variables in first-differences. The problem is then that, since we rely on Likert scale measured variables, baseline outsourcing levels could be correlated with the way that managers report changes in outsourcing. In other words, a plant with a baseline outsourcing level of 0 is more likely to experience an increase in outsourcing than a plant with a baseline level of $100 \%$. We can then rewrite (3) as

$$
\Delta \mathrm{Y}_{\mathrm{it}}=\beta \Delta \mathrm{X}_{\mathrm{it}}+\mathrm{BO}_{\mathrm{it}}+\Delta \mathrm{e}_{\mathrm{it}}
$$

where $\Delta \mathrm{u}_{\mathrm{it}}=\mathrm{BO}_{\mathrm{it}}+\Delta \mathrm{e}_{\mathrm{it}}$, and $\Delta \mathrm{e}_{\mathrm{it}}$ is iid. This is only a problem for consistency (and efficiency) if $\mathrm{BO}_{\mathrm{it}}$ is correlated with $\Delta \mathrm{X}_{\mathrm{it}}$ as this will bias our estimates of $\beta$ up or down depending on the sign of the correlation between the omitted variable and $\Delta \mathrm{X}_{\mathrm{it}}$.

We first address this concern by assuming that the level of outsourcing $\mathrm{BO}$ is a function $g($.$) of all other characteristics of the firm \mathrm{Z}$ such that $\mathrm{BO}=\mathrm{g}(\mathrm{Z})$ and therefore

$$
\Delta Y_{i t}=\beta \Delta X_{i t}+g\left(Z_{i t}\right)+\Delta e_{i t}
$$

We do not observe the function $g(Z)$ and therefore we substitute this by a second degree polynomial containing first degree interactions between all variables in $\mathrm{Z}$. We have looked for variables in our data set that may characterize firm size and outsourcing demand and included them in the regression together with their square values and their interactions with each other. These are the number of plant employees in 2005, the plant inauguration year, percentage of labor costs, percentage of workers with a high school 
diploma or equivalent, and the percentage of workers with a college degree. The inclusion of this second-degree polynomial of variables should pick up the potential omitted variable bias. ${ }^{11}$ We do this in specifications 3, 4, 9 and 10 in Table 5 and find that results are robust to the inclusion of this polynomial.

The second way to address this issue is by including a set of variables $Q_{i t}$ that affect the size of the plant and consequently the cost of service outsourcing such that

$$
\Delta \mathrm{Y}_{\mathrm{it}}=\beta \Delta \mathrm{X}_{\mathrm{it}}+\gamma \mathrm{Q}_{\mathrm{it}}+\Delta \mathrm{e}_{\mathrm{it}}
$$

These variables proxy for differences in costs and preferences across plants in outsourcing policies and therefore may be correlated with the underlying and unobserved level of service outsourcing. These are measures of whether manufacturing workers repair and maintain their own machines, whether HR services are outsourced and the percentage of laid off employees due to retirement or "other" causes. The first two variables are good proxies for whether a plant in particular has a strong preference or lower cost towards outsourcing as plants having their own workers repairing and maintaining machines are not outsourcing those services and plants outsourcing HR are more likely to outsource other related services. On the other hand, plants that report having laid off employess due to retirement or "other" causes (not relating labor productivity or misconduct) face lower costs of outsourcing services as they do not necessarily have to fire those workers formerly performing those services. See in specifications 5, 6, 11 and 12 in Table 5 that our results are robust to the inclusion of these variables and none of the new right-hand side variables seem to have any explanatory value.

\subsection{Discussion of Results}

There is little existing evidence on the relationship between market-level variables and firm structure as most work focuses on the relationship between organization decisions

\footnotetext{
${ }^{11}$ This methodology is very similar in spirit to the one used in the investment literature when investment is not observable but other measures of capital accumulation and firm characteristics are. See Levinshon and Petrin (2003) and De Loecker (2010) as examples.
} 
and factors such as technology, the nature of the transaction at hand or relative input prices. Therefore, there is not a clear link between our empirical results and existing theory.

To our knowledge, there are three potential channels that could link our results to theory. First, our market-side variables could be conditioning the nature of the contracting problem in Spanish manufacturing. Examples of these would be changes in the outside option of suppliers due to increases in competition or monitoring possibilities (as in De Bettignes, 2006) producing either a positive or negative correlation between market size or competition and outsourcing. Second, firm level factors could affect both market shares and outsourcing and therefore generating spurious correlations, as in Acemoglu et al. (2006). Third and last, firm scale could be very well affecting the optimal organizational form of the firm and therefore changing outsourcing practices, holding fixed the nature of the contracting problem, as in Grossman and Helpman (2002). We now discuss our empirical findings in relation to these potential channels.

As a starter, the finding that plants rely on outsourcing of services more when they obtain a larger market share is consistent with Adam Smith's claim that the degree of specialization (in our case more specialization means more outsourcing of peripheral activities) is limited by the extent of the market. Our findings show that as firms can exploit economies of scale in their core activities and increase their gains of specialization, the outsourcing of peripheral services grows as well. This is a bit different from the pin factory setting that Smith described as specialization occurred at the worker level and we are referring to the plant level, but still the mechanism in place would be the same. This explanation would fall into our third channel above where market size affects firm scale and triggers a change in outsourcing practices.

An easy way to rationalize this finding would be to think of each plant as one where the manager has to monitor and manage two activities (core and peripheral) within the firm to produce an item. These activities are perfect complements in that both are necessary for production. The core activity cannot be outsourced because the final product may lose all its value if so and it has potential gains of specialization. The peripheral activity may be outsourced and it has no gains of specialization (in other words, the plant demand for 
peripheral activities is fixed). If the plant manager has decreasing returns to scale in the number and intensity of tasks that has to monitor, he may decide to outsource the peripheral activity as long as the gains of specialization are larger than the costs of outsourcing. These may be both pecuniary as well as contracting costs since these peripheral services may be subject to moral hazard and specific investments in the idiosyncrasies of each plant.

The second of our robust results is that when plants face increasing competition they also increase their outsourcing of peripheral services to others. Our framework above is consistent with such correlation if an increase in competition increases the gains of specialization in the core activities relative to outsourcing costs. This would be consistent with the existing correlation between changes in outsourcing and changes in product prices and costs in some specifications as these may be indicative of relative increases in gains of exploiting economies of scale to the core manufacturing tasks.

On this regard, the first channel that we point out above falls into the realm of transaction cost economics predicting that an increase in quasi-rents due to specific investments increases the likelihood of in-house production. In our setting, we do not know how specific these peripheral services are but it seems fair to assume that all plants within an industry need of similar services and that these might be specific to idiosyncratic factors in particular plants. Since we do not observe quasi-rents and investment specificity, we are left with observing increases in competition faced by the plant. If the number of service suppliers stays constant, an increase in plant competition would increase the opportunity cost of the service provider firm and the likelihood of hold-up (holding constant competition in the service industry). If an increase in plant competition is correlated with an increase in the number of potential suppliers, the plant's opportunity cost would diminish and potentially see no change or increase in outsourcing. Therefore our finding suggests that either an increase in competition was followed by a larger increase in the number of potential outsourcing partners or that the TCE predictions cannot explain changes in outsourcing practices for peripheral services in Spanish manufacturing. 
On this same result, recent papers within property rights theories highlight the role of competition in make-or-buy decisions and show that there is a positive relationship between competition and outsourcing (De Bettignies, 2006) as the market can substitute for monitoring to discipline internal provision of effort. However, this is difficult to reconcile with our proposed framework above because our empirical setting is about peripheral low-value services and not core tasks to the firms' production.

Grossman and Helpman (2002) highlight the role of economies of scale in outsourcing decisions and show that this relation could go either way. If anything, we provide partial evidence that competition and outsourcing are positively correlated in our sample.

We also examine the empirical relevance of the second channel through the role of technology adoption in outsourcing decisions. Contrary to Acemoglu et al. (2006), we find no robust evidence that increases in technology adoption are correlated with service outsourcing decisions. This may be driven by the fact that ours is a sample of manufacturing plants and that we analyze outsourcing decisions of peripheral services. This means that predictions of property rights theories are halfway consistent with our results as on one hand we find a positive relation between outsourcing and competition and on the other we find no relationship with changes in technologies.

Finally, our results are also partially contradicting evidence of findings in Hortaçsu and Syverson (2009). The first difference between our paper and theirs is that we find that increases in market share or plant size are positively related to outsourcing while they report a positive relationship between vertical integration and plant size. This is not much of a problem because we are examining outsourcing of services and they examine outsourcing of material inputs. Second, contrary to them, we find that one-plant firms and multi-plant firms show the same patterns in changes of outsourcing and adjust their make-or-buy decisions in similar ways to different changes in their market environment.

Surprisingly enough there is not much evidence in the literature about the relation between vertical integration and either competition or market share as seen in Lafontaine and Slade (2007), or Bresnahan and Levin (2011) who review the relation between vertical integration and market structure through transaction characteristics and not variation in competition or market share within transaction features. This lack of 
evidence elsewhere reinforces the contribution of this paper as it may hopefully foster future empirical and theoretical research.

\section{Conclusions}

In this paper we have explored how plants within the Spanish manufacturing industry have changed their service outsourcing practices due to changes in their competitive environment. This empirical exercise sheds light at the make-or-buy decisions in a comprehensive manner since plants in our sample are spread across 12 manufacturing industries and therefore the analysis here departs from the industry-specific studies that have been flooding the empirical literature in vertical integration.

Our findings show that increases in the levels of outsourcing of peripheral services at the plant level are positively associated with increases in market share and market competition in our sample of 926 manufacturing Spanish plants. These results are not consistent with predictions from Transaction Cost Economics theories and only halfway consistent with Property Rights Theories predictions. Eventually the simple explanation that the degree of specialization is limited by the extent of the market seems to be the most reconciling explanation for all the patterns that we observe in our paper.

\section{References}

Abraham, K.G., and S. Taylor (1996). "Firms' Use of Outside Contractors: Theory and Evidence." Journal of Labor Economics, 14, 394-424.

Acemoglu, D., P. Aghion, R. Griffin and F. Zilibotti (2006) "Vertical Integration and Technology: Theory and Evidence," NBER Working Paper No. 10037.

Akerman, A. and L. Py (2011) "Outsourcing and the Division of Labor Between Firms: Evidence from Swedish Cities.” Mimeograph, Stockholm University.

Antras, P. and E. Helpman (2004) "Global Sourcing," Journal of Political Economy, $112(31), 552-580$.

Baker, G. and T. Hubbard (2003). "Make Versus Buy in Trucking: Asset Ownership, Job Design, and Information." American Economic Review 93: 551-572. 
Bayo-Moriones, A., J.E. Galdon-Sanchez and S. Martinez-de-Morentin (2013). "The Diffusion of Pay for Performance across Occupations". Forthcoming Industrial and Labor Relations Review.

Bresnahan, T., and J. Levin (2011). "Vertical Integration and Market Structure." Forthcoming in the Handbook of Organizational Economics, edited by John Roberts and Robert Gibbons.

Coase, R. (1937) “The Nature of the Firm”, Economica vol. 4(16), pp. 386-405.

De Bettignies, J. (2006) "Product Market Competition and the Boundaries of the Firm," Canadian Journal of Economics, vol. 39(3), 948-970.

De Loecker, J. (2010). "Product Differentiation, Multi-Product Firms and Estimating the Impact of Trade Liberalization on Productivity," forthcoming, Econometrica.

Forbes, Silke and Mara Lederman. 2009. "Adaptation and Vertical Integration in the Airline Industry." American Economic Review 99: 1831-49.

Gibbons, Robert. 2005. "Four Formal(izable) Theories of the Firm?" Journal of Economic Behavior and Organization 58: 202-247 (Sections 1-3).

Gibbons, R., Holden, R. and M. Powell (2011) "Organization and Information: Firms' Governance Choices in Rational-Expectations Equilibrium,” MIT Sloan Working Paper.

Griliches, Z., and D. Siegel (1992) "Purchased services, outsourcing, computers, and productivity in Manufacturing", pp 429-460, chapter printed in NBER Book "Output Measurement in the Service Sectors", edited by Zvi Griliches.

Grossman, S. and O. Hart (1986) "The Costs and Benefits of Ownership: A Theory of Vertical and Lateral Integration", Journal of Political Economy, vol. 94 (August), pp. 691-719.

Grossman, G. M. and E. Helpman (2002) "Integration Versus Outsourcing in Industry Equilibrium,” Quarterly Journal of Economics, vol. 117(1), pp. 121-148.

Holmstrom, Bengt and Paul Milgrom. 1991. "Multitask Principal-Agent Analyses: Incentive Contracts, Asset Ownership, and Job Design." Journal of Law, Economics and Organization 7: 24-52.

Hortaçsu, A. and C. Syverson (2009) "Why Do Firms Own Production Chains?" NBER Working Paper.

Lafontaine, F. and M. Slade (2007) "Vertical Integration and Firm Boundaries: The Evidence," Journal of Economic Literature, vol. 45(3), pp. 629-685. 
Legros, P. and A. Newman (2008) "Competitive Prices and Organizational Choices" manuscript. Coordinating Staffing Level and Service Quality," Management Science, Vol. 54, No. 2, pp. 369-383.

Levinsohn, J. and Petrin, A. 2003. Estimating Production Functions Using Inputs to Control for Unobservables., Review of Economic Studies, Vol. 70, pp. 317-342.

Macher, J. and Richman, B. (2008) "Transaction Cost Economics: An Assessment of Empirical Research in the Social Sciences.” Business and Politics 10 (1): Article 1.

Masten, S. (1984) "The Organization of Production: Evidence from the Aerospace Industry," Journal of Law \& Economics, vol. 27(2), pages 403-17.

Merino, F. and D. Rodriguez (2007). "Business services outsourcing by manufacturing firms." Industrial and Corporate Change, 16 (6), 1147-1173.

Monteverde, K. and D. Teece (1982) "Appropriable Rents and Quasi-Vertical Integration,” Journal of Law and Economics, vol. 25(2), pp. 321-328.

Ren, J. And Zhou, Y-P. 2008. "Call Center Outsourcing: Coordinating Staffing Level and Service Quality,” Management Science, 54: 369-383.

Simon, Herbert. 1951. "A Formal Theory of the Employment Relationship." Econometrica 19: 293-305.

Tiwana, A. and M. Keil (2007) "Does Peripheral Knowledge Complement Control? An Empirical Test in Technology Outsourcing Alliances," Strategic Management Journal, Vol. 28 (6), pp. 623-634.

Whinston, M. (2003) "On the Transaction-Cost Determinants of Vertical Integration", Journal of Law, Economics, and Organization, vol. 19(1), pp. 1-23.

Williamson, O. (1975) Markets and Hierarchies, New York: Free Press.

Woodruff, Christopher. 2002. "Non-contractible Investment and Vertical Integration in the Mexican Footwear Industry." International Journal of Industrial Organization 20: 1197-1224. 


\section{Appendix A}

Table A1. Percentage of fims by sec tor of a ctivity.

\begin{tabular}{|c|c|c|}
\hline SECTOR & $\begin{array}{l}\text { PERCENTAGE } \\
\text { IN THE SAMPLE }\end{array}$ & $\begin{array}{l}\text { PERCENUAGE IN } \\
\text { THE POPULATION }\end{array}$ \\
\hline Food, Beverages and Tobacco & 15,5 & 15,9 \\
\hline $\begin{array}{l}\text { Textile Industry, Wearing Apparel, Leather and } \\
\text { Footwear }\end{array}$ & 6,9 & 8,6 \\
\hline Wood and Cork & 3,4 & 2,6 \\
\hline Paper, Editing and Graphic Design & 7 & 8,1 \\
\hline Chemical Industry & 8 & 7,2 \\
\hline Rubberand Plastic Products & 6,7 & 6,0 \\
\hline Non-metallic Mineral Products & 10,8 & 9,7 \\
\hline Metallurgy and Fabric ated Mechanical Products & 15,4 & 15,4 \\
\hline Machinery and Mechanical Equipment & $\mathbf{7 , 5}$ & 8,0 \\
\hline $\begin{array}{l}\text { Eectrical, Electronic and Optical Products and } \\
\text { Equipment }\end{array}$ & $\mathbf{7 , 1}$ & 6,3 \\
\hline Transport Equipment & 6 & 6,5 \\
\hline Other Manufacturing Industries & 5,7 & 5,5 \\
\hline TOTAL & 100 & 100,0 \\
\hline
\end{tabular}

Source: DIRCE (Data INE 2005) and own elaboration from the BBVA's survey data.

Table A2. Perc entage of fims by size.

\begin{tabular}{|l|c|c|c|c|}
\hline & $\begin{array}{c}\mathbf{5 0} \text { and } 99 \\
\text { workers }\end{array}$ & $\begin{array}{c}\mathbf{1 0 0} \text { and } \mathbf{4 9 9} \\
\text { workers }\end{array}$ & $\begin{array}{c}\mathbf{5 0 0} \text { or more } \\
\text { workers }\end{array}$ & TOTAL \\
\hline PERC ENTAGE IN SAMPLE & 48,4 & 46,4 & 5,3 & 100 \\
\hline PERCENTAGE IN POPULATION & 54,2 & 40,7 & 5,1 & 100 \\
\hline
\end{tabular}

Source: DIRCE (Data INE 2005) and own elaboration from the BBVA's survey data. 


\section{Appendix B}

\section{Original Text in Spanish}

A13. ¿Cuál ha sido la evolución de los siguientes aspectos relacionados con su planta en los tres últimos años?

\begin{tabular}{|c|c|c|c|c|c|c|c|}
\hline & $\begin{array}{l}\text { Aumentó } \\
\text { mucho }\end{array}$ & $\begin{array}{l}\text { Aumentó } \\
\text { algo }\end{array}$ & $\begin{array}{l}\text { Permaneció } \\
\text { igual (No leer) }\end{array}$ & $\begin{array}{l}\text { Disminuyó } \\
\text { algo }\end{array}$ & $\begin{array}{l}\text { Disminuyó } \\
\text { mucho }\end{array}$ & Ns & Nc \\
\hline El número de empleados & 1 & 2 & 3 & 4 & 5 & 8 & 9 \\
\hline Los costes de producción & 1 & 2 & 3 & 4 & 5 & 8 & 9 \\
\hline $\begin{array}{l}\text { La calidad de sus } \\
\text { productos }\end{array}$ & 1 & 2 & 3 & 4 & 5 & 8 & 9 \\
\hline $\begin{array}{l}\text { El precio de sus } \\
\text { productos }\end{array}$ & 1 & 2 & 3 & 4 & 5 & 8 & 9 \\
\hline $\begin{array}{l}\text { La competencia en su } \\
\text { sector }\end{array}$ & 1 & 2 & 3 & 4 & 5 & 8 & 9 \\
\hline $\begin{array}{l}\text { La cuota de mercado de } \\
\text { la planta }\end{array}$ & 1 & 2 & 3 & 4 & 5 & 8 & 9 \\
\hline $\begin{array}{l}\text { La subcontratación de } \\
\text { servicios al exterior }\end{array}$ & 1 & 2 & 3 & 4 & 5 & 8 & 9 \\
\hline
\end{tabular}

A15. ¿Han tenido lugar cambios tecnológicos significativos en los últimos tres años en su planta o establecimiento? En ese sentido, diría Ud. que...
1. No ha habido ningún cambio
2. Se han introducido cambios sin importancia
3. Se han introducido cambios de cierta importancia
4. Se han introducido cambios muy importantes
5. Ha cambiado totalmente el sistema de producción

8. Ns

9. Nc

\section{Translation:}

A13: In the last three years, which has been the evolution of the following aspects related to your plant? Specify if they have increased a lot (1), increased some (2), remain largely unchanged (3), decreased some (4), decreased a lot (5), don't know (8) or don't answer (9).

Number of employees

Production costs

Quality of products

Price of products

Sector competition

Plant's market share

Service outsourcing from outside the firm

A15: In the last three years, have there been significant technological changes in your plant or establishment? In that sense, you would say that...

1. There has not been any change

2. There has been changes without importance

3. There has been changes of some importance

4. There has been very important changes

5. The whole production system has changed

8. Don't know

9. Don't answer 
Table 1A. Summary Statistics of Variables in Changes

\begin{tabular}{|c|c|c|c|c|c|c|c|c|c|c|c|}
\hline \multirow[b]{2}{*}{ Variable } & \multicolumn{3}{|c|}{ All Plants } & \multicolumn{3}{|c|}{ Independent Plants } & \multicolumn{5}{|c|}{ Integrated Plants } \\
\hline & Obs & Mean & Std. Dev. & Obs & Mean & Std. Dev & Obs & Mean & Std. Dev. & Diff & T-stat \\
\hline \multicolumn{12}{|l|}{ Likert Scales $[1,2,3,4,5]$} \\
\hline$\Delta$ Outsourcing? & 926 & 3.29 & 0.76 & 485 & 3.29 & 0.76 & 441 & 3.29 & 0.77 & 0.00 & 0.00 \\
\hline$\Delta$ Employees? & 1001 & 3.18 & 1.03 & 533 & 3.20 & 1.01 & 468 & 3.15 & 1.04 & 0.06 & 1.24 \\
\hline$\Delta$ Product Quality? & 988 & 3.78 & 0.65 & 529 & 3.76 & 0.64 & 459 & 3.80 & 0.65 & -0.04 & -1.45 \\
\hline $\begin{array}{l}\Delta \text { Product Cost? } \\
\Delta \text { Product Price? }\end{array}$ & $\begin{array}{l}962 \\
964\end{array}$ & $\begin{array}{l}3.65 \\
3.49\end{array}$ & $\begin{array}{l}0.88 \\
0.75\end{array}$ & $\begin{array}{l}513 \\
515\end{array}$ & $\begin{array}{l}3.71 \\
3.52\end{array}$ & $\begin{array}{l}0.88 \\
0.73\end{array}$ & $\begin{array}{l}449 \\
449\end{array}$ & $\begin{array}{l}3.59 \\
3.45\end{array}$ & $\begin{array}{l}0.88 \\
0.78\end{array}$ & $\begin{array}{l}\mathbf{0 . 1 3} \\
\mathbf{0 . 0 7}\end{array}$ & $\begin{array}{l}3.19 \\
2.18\end{array}$ \\
\hline$\Delta$ Competition? & 971 & 3.71 & 0.75 & 520 & 3.72 & 0.74 & 451 & 3.71 & 0.75 & 0.00 & 0.04 \\
\hline$\Delta$ Market Share? & 891 & 3.40 & 0.73 & 474 & 3.42 & 0.73 & 417 & 3.39 & 0.73 & 0.03 & 0.78 \\
\hline$\Delta$ Technology? & 998 & 2.62 & 1.18 & 531 & 2.57 & 1.16 & 467 & 2.69 & 1.21 & -0.11 & -2.16 \\
\hline \multicolumn{12}{|l|}{ Change Direction $[-1,0,+1]$} \\
\hline$\Delta$ Outsourcing? & 926 & 0.27 & 0.65 & 485 & 0.27 & 0.66 & 441 & 0.26 & 0.64 & 0.01 & 0.37 \\
\hline$\Delta$ Employees? & 1001 & 0.16 & 0.82 & 533 & 0.20 & 0.80 & 468 & 0.11 & 0.84 & 0.09 & 2.43 \\
\hline$\Delta$ Product Quality? & 988 & 0.67 & 0.49 & 529 & 0.66 & 0.50 & 459 & 0.69 & 0.49 & -0.02 & -1.11 \\
\hline$\Delta$ Product Cost? & 962 & 0.55 & 0.72 & 513 & 0.60 & 0.69 & 449 & 0.49 & 0.76 & 0.11 & 3.22 \\
\hline$\Delta$ Product Price? & 964 & 0.47 & 0.69 & 515 & 0.50 & 0.65 & 449 & 0.44 & 0.73 & 0.06 & 1.77 \\
\hline$\Delta$ Competition? & 971 & 0.59 & 0.55 & 520 & 0.59 & 0.55 & 451 & 0.58 & 0.55 & 0.01 & 0.37 \\
\hline$\Delta$ Market Share? & 891 & 0.38 & 0.67 & 474 & 0.39 & 0.67 & 417 & 0.36 & 0.66 & 0.04 & 1.11 \\
\hline \multicolumn{12}{|l|}{ Increase in Variable $[0,+1]$} \\
\hline Outsourcing Increase? & 926 & 0.38 & 0.49 & 485 & 0.39 & 0.49 & 441 & 0.37 & 0.48 & 0.02 & 0.88 \\
\hline Employee Increase? & 1001 & 0.43 & 0.50 & 533 & 0.44 & 0.50 & 468 & 0.42 & 0.49 & 0.03 & 1.26 \\
\hline Product Cost Increase? & 962 & 0.69 & 0.46 & 513 & 0.72 & 0.45 & 449 & 0.65 & 0.48 & 0.06 & 2.87 \\
\hline Product Quality Increase? & 988 & 0.69 & 0.46 & 529 & 0.67 & 0.47 & 459 & 0.70 & 0.46 & -0.02 & -1.07 \\
\hline Product Price Increase? & 964 & 0.59 & 0.49 & 515 & 0.59 & 0.49 & 449 & 0.58 & 0.49 & 0.00 & 0.13 \\
\hline Competition Increase? & 971 & 0.62 & 0.49 & 520 & 0.62 & 0.49 & 451 & 0.61 & 0.49 & 0.01 & 0.40 \\
\hline Market Share Increase? & 891 & 0.48 & 0.50 & 474 & 0.50 & 0.50 & 417 & 0.46 & 0.50 & 0.04 & 1.58 \\
\hline Technology Increase? & 998 & 0.27 & 0.44 & 531 & 0.24 & 0.43 & 467 & 0.30 & 0.46 & -0.06 & -3.17 \\
\hline
\end{tabular}

Note: This table provides summary statistics for all variables in changes used in this paper. Table 1B will do the same for variables in levels. See that the same variable is expressed in Likert scale values ranging from 1 to 5 where 1 means it decreased a lot and 5 means it increased a lot.

The exception here is $\Delta$ Technology where 1 means no increase and 5 changed completely

Variables in change of direction take values -1 if decreased, 0 if no change and +1 if increased.

Finally, the last set of variables asked the question whether there was an increase and therefore take value 1 if the variable increased and 0 if there was no change or decreased.

The last two columns provide differences between integrated and independent plants and the t-statistic of those differences. We mark in bold those that are significant. 
Table 1B. Summary Statistics of All Variables in Levels

\begin{tabular}{|c|c|c|c|c|c|c|c|c|c|c|c|c|c|}
\hline \multirow[b]{2}{*}{ Variable } & \multirow[b]{2}{*}{ Obs } & \multirow[b]{2}{*}{ Mean } & \multirow[b]{2}{*}{ Std. Dev } & \multirow[b]{2}{*}{ Min } & \multirow[b]{2}{*}{ Max } & \multicolumn{3}{|c|}{ Single-Plant Firms } & \multicolumn{3}{|c|}{ Multi-Plant Firms } & \multirow[b]{2}{*}{ Diff } & \multirow[b]{2}{*}{ T-stat } \\
\hline & & & & & & Obs & Mean & Std. Dev. & Obs & Mean & Std. Dev & & \\
\hline Number of Employees & 1001 & 188.01 & 467.87 & 21 & 12810 & 534 & 118.04 & 125.73 & 467 & 268.01 & 663.06 & -149.96 & -7.03 \\
\hline First Year of Plant & 979 & 1969.11 & 29.37 & 1700 & 2006 & 525 & 1969.24 & 25.82 & 454 & 1968.96 & 33.03 & 0.28 & 0.21 \\
\hline Multi-Plant Firm? & 1003 & 0.47 & 0.50 & 0 & 1 & 534 & 0.00 & 0.00 & 469 & 1.00 & 0.00 & -1.00 & - \\
\hline Pctg Labor Cost & 756 & 31.67 & 17.22 & 1 & 90 & 410 & 32.09 & 17.45 & 346 & 31.18 & 16.96 & 0.90 & 1.02 \\
\hline Outsourced Recruiting & 997 & 0.05 & 0.21 & 0 & 1 & 531 & 0.03 & 0.18 & 466 & 0.06 & 0.24 & -0.03 & -2.99 \\
\hline Pctg Retirees & 784 & 0.15 & 0.29 & 0 & 1 & 422 & 0.13 & 0.29 & 362 & 0.17 & 0.30 & -0.04 & -2.99 \\
\hline Pctg Laid Off Other & 782 & 0.05 & 0.16 & 0 & 1 & 421 & 0.04 & 0.14 & 361 & 0.07 & 0.18 & -0.03 & -3.72 \\
\hline Pctg College Degree & 985 & 7.14 & 10.90 & 0 & 98 & 525 & 6.22 & 10.11 & 460 & 8.19 & 11.65 & -1.97 & -4.00 \\
\hline Pctg High School Degree & 955 & 33.55 & 27.73 & 0 & 100 & 511 & 33.34 & 28.69 & 444 & 33.80 & 26.61 & -0.47 & -0.37 \\
\hline Workers Prepare Machines? & 990 & 6.28 & 3.32 & 0 & 10 & 528 & 6.20 & 3.42 & 462 & 6.37 & 3.21 & -0.17 & -1.15 \\
\hline Workers Do Maintenance? & 988 & 4.57 & 3.28 & 0 & 10 & 529 & 4.71 & 3.35 & 459 & 4.42 & 3.19 & 0.29 & 1.95 \\
\hline
\end{tabular}

Note: This table provides summary statistics for all variables in levels used in our analysis. We also break statistics by whether the plant belongs to a single-plant or multi-plant firm. Finally, we provide the difference and its t-statistic of variables between independent and integrated plants. We write in bold those that are statistically significant. 
Table 2. Changes in Outsourcing of Services by Industry

\begin{tabular}{|c|c|c|c|c|}
\hline & $\%$ Decrease & \% No Change & $\%$ Increase & Total \\
\hline Food, Beverage and Tobacco & 0.05 & 0.59 & 0.36 & 132 \\
\hline Textile & 0.12 & 0.64 & 0.24 & 59 \\
\hline Wood and Cork & 0.16 & 0.52 & 0.32 & 31 \\
\hline Paper and Graphical Arts & 0.14 & 0.50 & 0.36 & 66 \\
\hline Chemical Industry & 0.07 & 0.53 & 0.41 & 74 \\
\hline Plastics & 0.26 & 0.46 & 0.28 & 65 \\
\hline Mineral Products no Metals & 0.07 & 0.55 & 0.38 & 103 \\
\hline Metalic Products & 0.12 & 0.49 & 0.38 & 146 \\
\hline Mechanical Equipment & 0.08 & 0.45 & 0.46 & 71 \\
\hline Electrical Equipment & 0.18 & 0.32 & 0.50 & 68 \\
\hline Transportation Equipment & 0.07 & 0.44 & 0.49 & 57 \\
\hline Other Manufacturing Industries & 0.15 & 0.46 & 0.39 & 54 \\
\hline Total & 0.11 & 0.50 & 0.38 & 926 \\
\hline
\end{tabular}

Note: This Table decomposes the dependent variable in this study "How has outsourcing changed in the last 3 years in your plant?" by industry and for all the 926 for which this information is available. Similarly, this table also provides information regarding the number of plants available per industry in our sample. 
Table 3. OLS and Ordered Logit (OL) Regressions of Measures of Changes in Outsourcing on Changes of Other Variables

Dep Var: $\Delta$ Outsourcing? $\quad$ Likert Scale Values $[1,2,3,4,5]$

\begin{tabular}{|c|c|c|c|c|c|}
\hline & (1) & (2) & (3) & (4) & (5) \\
\hline & OLS & OLS & OLS & OLS & OL \\
\hline$\Delta$ Employees? & $\begin{array}{c}0.0299 \\
(0.3190)\end{array}$ & $\begin{array}{c}0.0298 \\
(0.3210)\end{array}$ & $\begin{array}{c}0.0274 \\
(0.3610)\end{array}$ & $\begin{array}{c}0.0272 \\
(0.3650)\end{array}$ & $\begin{array}{c}0.095 \\
(0.2570)\end{array}$ \\
\hline$\Delta$ Product Quality? & $\begin{array}{c}0.0253 \\
(0.5770)\end{array}$ & $\begin{array}{c}0.0296 \\
(0.5130)\end{array}$ & $\begin{array}{c}0.0241 \\
(0.5930)\end{array}$ & $\begin{array}{l}0.027 \\
(0.5470)\end{array}$ & $\begin{array}{l}0.0625 \\
(0.5980)\end{array}$ \\
\hline$\Delta$ Product Cost? & $\begin{array}{c}0.0193 \\
(0.5590)\end{array}$ & $\begin{array}{c}0.0185 \\
(0.5770)\end{array}$ & $\begin{array}{c}0.0193 \\
(0.5590)\end{array}$ & $\begin{array}{c}0.0185 \\
(0.5740)\end{array}$ & $\begin{array}{c}0.0604 \\
(0.5060)\end{array}$ \\
\hline$\Delta$ Product Price? & $\begin{array}{c}0.0747^{* *} \\
(0.0373)\end{array}$ & $\begin{array}{c}0.0751^{* *} \\
(0.0362)\end{array}$ & $\begin{array}{c}0.0712 * \\
(0.0513)\end{array}$ & $\begin{array}{c}0.0716^{* *} \\
(0.0498)\end{array}$ & $\begin{array}{l}0.1631 \\
(0.1150)\end{array}$ \\
\hline$\Delta$ Competition? & $\begin{array}{c}0.0844 * * \\
(0.0290)\end{array}$ & $\begin{array}{c}0.0840^{* *} \\
(0.0299)\end{array}$ & $\begin{array}{c}0.0881^{* *} \\
(0.0259)\end{array}$ & $\begin{array}{c}0.0878^{* *} \\
(0.0265)\end{array}$ & $\begin{array}{c}0.2336 * * \\
(0.0314)\end{array}$ \\
\hline$\Delta$ Market Share? & $\begin{array}{c}0.2249 * * * \\
(0.0000)\end{array}$ & $\begin{array}{c}0.2276 * * * \\
(0.0000)\end{array}$ & $\begin{array}{c}0.2211^{* * * *} \\
(0.0000)\end{array}$ & $\begin{array}{c}0.2232 * * * \\
(0.0000)\end{array}$ & $\begin{array}{c}0.6234 * * * \\
(0.0000)\end{array}$ \\
\hline Integrated Plant? & $\begin{array}{c}0.0005 \\
(0.9920)\end{array}$ & $\begin{array}{c}0.0009 \\
(0.9870)\end{array}$ & $\begin{array}{c}-0.0005 \\
(0.9930)\end{array}$ & $\begin{array}{c}-0.0003 \\
(0.9960)\end{array}$ & $\begin{array}{c}-0.0395 \\
(0.7840)\end{array}$ \\
\hline$\Delta$ Technology? & $\begin{array}{c}0.0233 \\
(0.2860)\end{array}$ & & $\begin{array}{c}0.0218 \\
(0.3190)\end{array}$ & & $\begin{array}{l}0.0642 \\
(0.2670)\end{array}$ \\
\hline Technology Increase? & & $\begin{array}{l}0.031 \\
(0.6010)\end{array}$ & & $\begin{array}{c}0.0378 \\
(0.5260)\end{array}$ & \\
\hline Constant & $\begin{array}{c}1.6209 * * * \\
(0.0000)\end{array}$ & $\begin{array}{c}1.6520 * * * \\
(0.0000)\end{array}$ & $\begin{array}{c}1.6492 * * * \\
(0.0000)\end{array}$ & $\begin{array}{c}1.6815^{* * *} \\
(0.0000)\end{array}$ & \\
\hline Industry FE & No & No & Yes & Yes & Yes \\
\hline Observations & 815 & 815 & 815 & 815 & 815 \\
\hline R-squared & 0.08 & 0.079 & 0.098 & 0.098 & - \\
\hline
\end{tabular}

Change Direction $[-1,0,+1]$

(6)

OLS

(7)

(8)

OL

OLS

$-0.0006$

$(0.9840)$

0.0009

$0.9850)$

$0.0563^{*}$

0.0569*

$(0.0920)$

0.0561

$(0.1690)$

$0.2202^{* * *}$

$(0.0000)$

$-0.0139$

$(0.7500)$

$\begin{array}{ccc}0.0322 & 0.0368 & 0.1251 \\ (0.5200) & (0.4640) & (0.4370) \\ 0.0818 & 0.0865 & \\ (0.1390) & (0.1170) & \\ & & \\ \text { No } & \text { Yes } & \text { Yes } \\ & & \\ 815 & 815 & 815 \\ 0.07 & 0.09 & -\end{array}$

Increase Outsourcing?

(9)

(10)

OLS

OLS

$0.0134 \quad 0.0131$

$\begin{array}{ll}(0.7170) & (0.7220)\end{array}$

$0.0096 \quad 0.0027$

(0.7930) $\quad(0.9410)$

$0.0347 \quad 0.0394$

$(0.3400) \quad(0.2760)$

$0.0593 * \quad 0.0578 *$

$(0.0786) \quad(0.0893)$

$0.0639 * \quad 0.0726 * *$

$(0.0597) \quad(0.0352)$

$0.1920^{* * *} \quad 0.1882^{* *}$

$(0.0000) \quad(0.0000)$

$-0.0287 \quad-0.0408$

$\begin{array}{ll}(0.3860) & (0.2330)\end{array}$

$0.03 \quad 0.0411$

$(0.4350) \quad(0.2850)$

$0.1700^{* * *} \quad 0.1716^{* * *}$

(0.0002) (0.0003)

No Yes

$815 \quad 815$

Note: This table presents evidence of running OLS and OL regressions of changes in outsourcing on changes in every other variable available in changes.

See that specifications 1 to 5 use measures of Likert scales for both dependent and independent variables; specifications 6 to 8 use measures of changes in

direction taking values $-1,0$ or +1 for both dependent and independent variables; and finally, specifications 9 and 10 use variables that denote whether the changing

variable has increased or not.

P-values from robust standard errors in parentheses, ${ }^{* * *} \mathrm{p}<0.01,{ }^{* *} \mathrm{p}<0.05,{ }^{*} \mathrm{p}<0.1$ 
Table 4. Changes in Outsourcing in Single-Plant Firms and Multi-Plant Firms

\begin{tabular}{|c|c|c|c|c|c|c|c|c|}
\hline \multirow[t]{3}{*}{ Dep Var: $\Delta$ Outsourcing? } & \multicolumn{4}{|c|}{ Likert Scale Values $[1,2,3,4,5]$} & \multicolumn{4}{|c|}{ Change Direction $[-1,0,+1]$} \\
\hline & (1) & (2) & (3) & (4) & (5) & (6) & (7) & (8) \\
\hline & OLS & OLS & OL & OL & OLS & OLS & OL & OL \\
\hline$\Delta$ Employees? & $\begin{array}{c}0.0626 \\
(0.1260)\end{array}$ & $\begin{array}{c}0.0583 \\
(0.1560)\end{array}$ & $\begin{array}{c}0.1972 * \\
(0.0959)\end{array}$ & $\begin{array}{c}0.1843 \\
(0.1210)\end{array}$ & $\begin{array}{c}0.0309 \\
(0.5130)\end{array}$ & $\begin{array}{c}0.0268 \\
(0.5690)\end{array}$ & $\begin{array}{c}0.1105 \\
(0.4680)\end{array}$ & $\begin{array}{c}0.0955 \\
(0.5300)\end{array}$ \\
\hline$\Delta$ Product Quality? & $\begin{array}{c}0.0775 \\
(0.2060)\end{array}$ & $\begin{array}{l}0.073 \\
(0.2250)\end{array}$ & $\begin{array}{c}0.2034 \\
(0.2110)\end{array}$ & $\begin{array}{c}0.1932 \\
(0.2350)\end{array}$ & $\begin{array}{c}0.0253 \\
(0.7100)\end{array}$ & $\begin{array}{l}0.0291 \\
(0.6640)\end{array}$ & $\begin{array}{c}0.0934 \\
(0.6720)\end{array}$ & $\begin{array}{c}0.0989 \\
(0.6500)\end{array}$ \\
\hline$\Delta$ Product Cost? & $\begin{array}{l}0.0191 \\
(0.6660)\end{array}$ & $\begin{array}{l}0.0177 \\
(0.6900)\end{array}$ & $\begin{array}{c}0.0313 \\
(0.8000)\end{array}$ & $\begin{array}{c}0.0369 \\
(0.7660)\end{array}$ & $\begin{array}{c}0.0498 \\
(0.3080)\end{array}$ & $\begin{array}{c}0.0455 \\
(0.3510)\end{array}$ & $\begin{array}{c}0.1461 \\
(0.3530)\end{array}$ & $\begin{array}{c}0.1428 \\
(0.3640)\end{array}$ \\
\hline$\Delta$ Product Price? & $\begin{array}{l}0.0107 \\
(0.8220)\end{array}$ & $\begin{array}{l}0.0077 \\
(0.8750)\end{array}$ & $\begin{array}{c}-0.0039 \\
(0.9770)\end{array}$ & $\begin{array}{l}-0.029 \\
(0.8340)\end{array}$ & $\begin{array}{c}-0.0004 \\
(0.9930)\end{array}$ & $\begin{array}{c}-0.0032 \\
(0.9490)\end{array}$ & $\begin{array}{l}-0.011 \\
(0.9450)\end{array}$ & $\begin{array}{c}-0.0427 \\
(0.7930)\end{array}$ \\
\hline$\Delta$ Competition? & $\begin{array}{c}0.0923^{*} \\
(0.0605)\end{array}$ & $\begin{array}{c}0.0993^{* *} \\
(0.0489)\end{array}$ & $\begin{array}{l}0.2071 \\
(0.1290)\end{array}$ & $\begin{array}{c}0.2397^{*} \\
(0.0930)\end{array}$ & $\begin{array}{c}0.064 \\
(0.2770)\end{array}$ & $\begin{array}{c}0.0661 \\
(0.2650)\end{array}$ & $\begin{array}{c}0.2286 \\
(0.2310)\end{array}$ & $\begin{array}{c}0.2463 \\
(0.2070)\end{array}$ \\
\hline$\Delta$ Market Share? & $\begin{array}{c}0.1239 * * \\
(0.0415)\end{array}$ & $\begin{array}{c}0.1188 * * \\
(0.0490)\end{array}$ & $\begin{array}{c}0.3637^{* *} \\
(0.0453)\end{array}$ & $\begin{array}{c}0.3617^{* *} \\
(0.0456)\end{array}$ & $\begin{array}{c}0.1494^{* *} \\
(0.0110)\end{array}$ & $\begin{array}{c}0.1405^{* *} \\
(0.0174)\end{array}$ & $\begin{array}{c}0.4719 * * \\
(0.0177)\end{array}$ & $\begin{array}{c}0.4545^{* *} \\
(0.0237)\end{array}$ \\
\hline Technology Increase? & $\begin{array}{c}-0.0154 \\
(0.8570)\end{array}$ & $\begin{array}{c}-0.0145 \\
(0.8650)\end{array}$ & $\begin{array}{r}-0.036 \\
(0.8770)\end{array}$ & $\begin{array}{c}-0.0365 \\
(0.8780)\end{array}$ & $\begin{array}{c}0.0028 \\
(0.9700)\end{array}$ & $\begin{array}{r}0.0037 \\
(0.9610)\end{array}$ & $\begin{array}{c}0.0166 \\
(0.9440)\end{array}$ & $\begin{array}{c}0.0143 \\
(0.9520)\end{array}$ \\
\hline Multi-Plant Firm? & $\begin{array}{c}-0.5192 \\
(0.3340)\end{array}$ & $\begin{array}{c}-0.5394 \\
(0.3220)\end{array}$ & $\begin{array}{l}-1.827 \\
(0.2230)\end{array}$ & $\begin{array}{c}-1.9112 \\
(0.2150)\end{array}$ & $\begin{array}{l}-0.077 \\
(0.4380)\end{array}$ & $\begin{array}{c}-0.0848 \\
(0.4020)\end{array}$ & $\begin{array}{c}-0.2665 \\
(0.3980)\end{array}$ & $\begin{array}{c}-0.3089 \\
(0.3440)\end{array}$ \\
\hline Multi-Plant Firm?* $\Delta$ Employees? & $\begin{array}{c}-0.0621 \\
(0.2990)\end{array}$ & $\begin{array}{c}-0.0562 \\
(0.3410)\end{array}$ & $\begin{array}{c}-0.1879 \\
(0.2650)\end{array}$ & $\begin{array}{c}-0.1757 \\
(0.2930)\end{array}$ & $\begin{array}{c}-0.0592 \\
(0.3430)\end{array}$ & $\begin{array}{c}-0.0542 \\
(0.3820)\end{array}$ & $\begin{array}{c}-0.2147 \\
(0.2790)\end{array}$ & $\begin{array}{c}-0.2019 \\
(0.3080)\end{array}$ \\
\hline Multi-Plant Firm?*ム Product Quality? & $\begin{array}{c}-0.1089 \\
(0.2250)\end{array}$ & $\begin{array}{c}-0.1037 \\
(0.2490)\end{array}$ & $\begin{array}{c}-0.2883 \\
(0.2240)\end{array}$ & $\begin{array}{c}-0.2832 \\
(0.2400)\end{array}$ & $\begin{array}{c}-0.0592 \\
(0.5380)\end{array}$ & $\begin{array}{c}-0.0677 \\
(0.4790)\end{array}$ & $\begin{array}{c}-0.2146 \\
(0.4890)\end{array}$ & $\begin{array}{c}-0.2384 \\
(0.4430)\end{array}$ \\
\hline Multi-Plant Firm?* $\Delta$ Product Cost? & $\begin{array}{c}-0.0045 \\
(0.9450)\end{array}$ & $\begin{array}{l}-0.002 \\
(0.9750)\end{array}$ & $\begin{array}{c}0.0358 \\
(0.8450)\end{array}$ & $\begin{array}{c}0.0345 \\
(0.8510)\end{array}$ & $\begin{array}{c}0.0128 \\
(0.8460)\end{array}$ & $\begin{array}{c}0.0235 \\
(0.7200)\end{array}$ & $\begin{array}{l}0.0518 \\
(0.8050)\end{array}$ & $\begin{array}{c}0.0751 \\
(0.7190)\end{array}$ \\
\hline Multi-Plant Firm $? * \Delta$ Product Price? & $\begin{array}{c}0.1198 * \\
(0.0938)\end{array}$ & $\begin{array}{c}0.1183 \\
(0.1020)\end{array}$ & $\begin{array}{c}0.3744^{*} \\
(0.0629)\end{array}$ & $\begin{array}{c}0.3864 * \\
(0.0594)\end{array}$ & $\begin{array}{c}0.1019 \\
(0.1310)\end{array}$ & $\begin{array}{c}0.0973 \\
(0.1510)\end{array}$ & $\begin{array}{c}0.3383 \\
(0.1160)\end{array}$ & $\begin{array}{c}0.3473 \\
(0.1090)\end{array}$ \\
\hline Multi-Plant Firm?* $\Delta$ Competition? & $\begin{array}{c}-0.0013 \\
(0.9870)\end{array}$ & $\begin{array}{c}-0.0099 \\
(0.8980)\end{array}$ & $\begin{array}{l}0.0307 \\
(0.8840)\end{array}$ & $\begin{array}{c}0.0219 \\
(0.9180)\end{array}$ & $\begin{array}{c}-0.0107 \\
(0.8950)\end{array}$ & $\begin{array}{c}-0.0135 \\
(0.8690)\end{array}$ & $\begin{array}{c}-0.0347 \\
(0.8940)\end{array}$ & $\begin{array}{c}-0.0258 \\
(0.9230)\end{array}$ \\
\hline 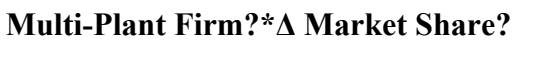 & $\begin{array}{c}0.2098 * * \\
(0.0188)\end{array}$ & $\begin{array}{c}0.2108^{* *} \\
(0.0174)\end{array}$ & $\begin{array}{c}0.5502^{* *} \\
(0.0316)\end{array}$ & $\begin{array}{c}0.5515^{* *} \\
(0.0303)\end{array}$ & $\begin{array}{c}0.1382^{*} \\
(0.0860)\end{array}$ & $\begin{array}{c}0.1450 * \\
(0.0710)\end{array}$ & $\begin{array}{c}0.4780 * \\
(0.0731)\end{array}$ & $\begin{array}{c}0.5002^{*} \\
(0.0622)\end{array}$ \\
\hline Multi-Plant Firm?*Technology Increas & $\begin{array}{c}0.074 \\
(0.5350)\end{array}$ & $\begin{array}{c}0.0874 \\
(0.4630)\end{array}$ & $\begin{array}{c}0.1786 \\
(0.5790)\end{array}$ & $\begin{array}{c}0.2169 \\
(0.5050)\end{array}$ & $\begin{array}{c}0.0443 \\
(0.6600)\end{array}$ & $\begin{array}{c}0.0535 \\
(0.5950)\end{array}$ & $\begin{array}{l}0.133 \\
(0.6780)\end{array}$ & $\begin{array}{c}0.1676 \\
(0.6040)\end{array}$ \\
\hline Constant & $\begin{array}{c}1.9274 * * * \\
\quad(0.0000)\end{array}$ & $\begin{array}{c}1.9666^{* * *} \\
(0.0000)\end{array}$ & & & $\begin{array}{c}0.1228 * \\
(0.0897)\end{array}$ & $\begin{array}{c}0.1295^{*} \\
(0.0749)\end{array}$ & & \\
\hline Industry FE & No & Yes & No & Yes & No & Yes & No & Yes \\
\hline Number Groups & - & - & - & - & - & - & - & - \\
\hline Observations & 815 & 815 & 815 & 815 & 815 & 815 & 815 & 815 \\
\hline R-squared & 0.093 & 0.112 & - & - & 0.079 & 0.098 & - & - \\
\hline
\end{tabular}

Note; This table provides OLS and Ordered Logit regressions for changes in outsourcing on changes of other variables with interactions with a dummy variable that takes value 1 if plant is integrated in a larger firm, and 0 otherwise.

See that specifications 1 to 4 use Likert scale measures for both dependent and independent variables while specifications 5 to 8 use changes in direction.

P-values from robust standard errors in parentheses, ${ }^{* * *} \mathrm{p}<0.01,{ }^{* *} \mathrm{p}<0.05,{ }^{*} \mathrm{p}<0.1$. 
Dep Var: $\Delta$ Outsourcing?

\section{Likert Scale Values $[1,2,3,4,5]$}

(4)

$\Delta$ Employees?

$\Delta$ Product Quality?

$\Delta$ Product Cost?

$\Delta$ Product Price?

$\Delta$ Competition?

$\Delta$ Market Share?

Integrated Plant?

Technology Increase?

Number of Employees

First Year of Plant

Petg Labor Cost

Pctg College Degree

Pctg High School Degree

Workers Prepare Machines?

\begin{tabular}{|c|c|c|c|c|c|}
\hline-0.0077 & -0.0061 & -0.0168 & -0.0162 & 0.0387 & 0.0358 \\
\hline$(0.8240)$ & $(0.8600)$ & $(0.6220)$ & $(0.6380)$ & $(0.2600)$ & $(0.2930)$ \\
\hline 0.021 & 0.0205 & 0.0072 & 0.0074 & 0.0109 & 0.0138 \\
\hline$(0.6980)$ & $(0.7040)$ & $(0.8970)$ & $(0.8940)$ & $(0.8350)$ & $(0.7930)$ \\
\hline 0.0252 & 0.0176 & 0.0265 & 0.0197 & 0.0095 & 0.0091 \\
\hline$(0.5210)$ & $(0.6520)$ & $(0.5050)$ & $(0.6190)$ & $(0.7930)$ & $(0.8010)$ \\
\hline $\begin{array}{c}0.0707 * \\
(0.0881)\end{array}$ & $\begin{array}{l}0.0686 \\
(0.1030)\end{array}$ & $\begin{array}{c}0.064 \\
(0.1240)\end{array}$ & $\begin{array}{c}0.062 \\
(0.1420)\end{array}$ & $\begin{array}{c}0.0755^{*} \\
(0.0694)\end{array}$ & $\begin{array}{l}0.0702 \\
(0.1010)\end{array}$ \\
\hline $0.1148^{* *}$ & $0.1109 * *$ & $0.1082^{* *}$ & $0.1064^{* *}$ & $0.0777 *$ & $0.0801^{*}$ \\
\hline $\begin{array}{c}(0.0112) \\
0.2438 * * *\end{array}$ & $\begin{array}{c}(0.0165) \\
0.2346 * * *\end{array}$ & $\begin{array}{c}(0.0185) \\
0.2377^{* * *}\end{array}$ & $\begin{array}{c}(0.0237) \\
0.2297 * * *\end{array}$ & $\begin{array}{c}(0.0731) \\
0.2165 * * *\end{array}$ & $\begin{array}{c}(0.0714) \\
0.2073 * * *\end{array}$ \\
\hline $\begin{array}{c}0.2438 \times 1.7 x \\
(0.0000)\end{array}$ & $\begin{array}{l}0.2340 \\
(0.0000)\end{array}$ & $(0.0000)$ & $(0.0000)$ & $(0.0001)$ & $(0.0001)$ \\
\hline $\begin{array}{c}-0.0101 \\
(0.8710)\end{array}$ & $\begin{array}{c}-0.0031 \\
(0.9620)\end{array}$ & $\begin{array}{c}-0.0114 \\
(0.8620)\end{array}$ & $\begin{array}{c}-0.0112 \\
(0.8700)\end{array}$ & $\begin{array}{c}-0.0305 \\
(0.6130)\end{array}$ & $\begin{array}{c}-0.0236 \\
(0.7010)\end{array}$ \\
\hline $\begin{array}{l}0.0018 \\
(0.9800)\end{array}$ & $\begin{array}{l}0.0046 \\
(0.9500)\end{array}$ & $\begin{array}{c}-0.0021 \\
(0.9770)\end{array}$ & $\begin{array}{l}0.0027 \\
(0.9710)\end{array}$ & $\begin{array}{l}0.0653 \\
(0.3430)\end{array}$ & $\begin{array}{l}0.0713 \\
(0.3060)\end{array}$ \\
\hline 0.0001 & 0.0000 & 0.0011 & 0.0009 & & \\
\hline$(0.1050)$ & $(0.2620)$ & $(0.8070)$ & $(0.8420)$ & & \\
\hline 0.0001 & 0.0002 & -0.0291 & -0.0263 & & \\
\hline$(0.9210)$ & $(0.8830)$ & $(0.5450)$ & $(0.5830)$ & & \\
\hline $\begin{array}{c}-0.0003 \\
(0.8410)\end{array}$ & $\begin{array}{c}-0.0005 \\
(0.7570)\end{array}$ & $\begin{array}{c}0.2107 * \\
(0.0668)\end{array}$ & $\begin{array}{c}0.2189 * \\
(0.0564)\end{array}$ & & \\
\hline $0.0077 * *$ & $0.0079 * *$ & $0.3433^{*}$ & $0.3475^{*}$ & & \\
\hline$(0.0223)$ & $(0.0237)$ & $(0.0613)$ & $(0.0569)$ & & \\
\hline \multirow[t]{10}{*}{$\begin{array}{c}0.0003 \\
(0.7940)\end{array}$} & $\begin{array}{c}-0.0001 \\
(0.9250)\end{array}$ & $\begin{array}{c}0.0517 \\
(0.5230)\end{array}$ & $\begin{array}{c}0.0632 \\
(0.4430)\end{array}$ & & \\
\hline & & & & $\begin{array}{c}-0.0143 \\
(0.1590)\end{array}$ & $\begin{array}{c}-0.0143 \\
(0.1640)\end{array}$ \\
\hline & & & & -0.005 & -0.0067 \\
\hline & & & & $(0.6340)$ & $(0.5280)$ \\
\hline & & & & 0.0976 & 0.0842 \\
\hline & & & & $(0.3210)$ & $(0.3910)$ \\
\hline & & & & -0.0459 & -0.055 \\
\hline & & & & $(0.7740)$ & $(0.7300)$ \\
\hline & & & & 0.1026 & 0.1075 \\
\hline & & & & $(0.5150)$ & $(0.4840)$ \\
\hline 1.3787 & 1.3776 & 24.1332 & 21.2512 & $1.8901 * * *$ & $1.9355^{* * * *}$ \\
\hline$(0.4990)$ & $(0.5000)$ & $(0.6040)$ & $(0.6460)$ & $(0.0000)$ & $(0.0000)$ \\
\hline
\end{tabular}

Workers Do Maintenance?

Pctg Retirees

\section{Pctg Laid Off Other}

Outsourced Recruiting

Constant

Industry FE

Polinomial

Observations

R-squared
$(0.4990) \quad(0.5000)$

No No

619

0.09

\section{No}

619

0.10

No Yes

No

Yes

619

0.13

\begin{abstract}
Yes No Yes
\end{abstract}
Yes

619

$\begin{array}{ll}\text { No } & \text { Yes } \\ \text { No } & \text { No } \\ 634 & 634 \\ 0.08 & 0.09\end{array}$

Change Direction $[-1,0,+1]$

$\begin{array}{cccccc}-0.047 & -0.0452 & -0.0507 & -0.0494 & 0.0005 & -0.0019 \\ (0.1980) & (0.2150) & (0.1580) & (0.1710) & (0.9880) & (0.9560) \\ 0.0073 & 0.0084 & -0.018 & -0.0168 & -0.0148 & -0.0143 \\ (0.8970) & (0.8790) & (0.7480) & (0.7620) & (0.7870) & (0.7920) \\ 0.0707^{*} & 0.0660^{*} & 0.0686^{*} & 0.0648 * & 0.0422 & 0.0448 \\ (0.0689) & (0.0864) & (0.0796) & (0.0962) & (0.2570) & (0.2260) \\ 0.0585 & 0.054 & 0.0584 & 0.0537 & 0.0539 & 0.0453 \\ (0.1240) & (0.1630) & (0.1250) & (0.1650) & (0.1640) & (0.2550) \\ 0.0978^{* *} & 0.0903^{*} & 0.0884^{*} & 0.0836^{*} & 0.0604 & 0.0632 \\ (0.0402) & (0.0664) & (0.0665) & (0.0916) & (0.1880) & (0.1790) \\ 0.2354^{* * *} & 0.2263^{* * *} & 0.2288^{* * *} & 0.2208^{* * *} & 0.2224^{* * *} & 0.2117 * * * \\ (0.0000) & (0.0000) & (0.0000) & (0.0000) & (0.0000) & (0.0000) \\ -0.0283 & -0.0272 & -0.0194 & -0.0238 & -0.0431 & -0.044 \\ (0.5880) & (0.6170) & (0.7230) & (0.6780) & (0.3950) & (0.3960) \\ 0.006 & 0.0045 & 0.0045 & 0.0051 & 0.0678 & 0.0741 \\ (0.9170) & (0.9390) & (0.9390) & (0.9330) & (0.2370) & (0.1970) \\ 0.0001 * & 0.0000 & -0.0007 & -0.0009 & & \end{array}$

$\begin{array}{cccc}0.0001 * & 0.0000 & -0.0007 & -0.0009\end{array}$

$\begin{array}{cccc}(0.0760) & (0.1890) & (0.8770) & (0.8280) \\ 0.0004 & 0.0004 & -0.0254 & -0.0236\end{array}$

$\begin{array}{llll}0.0004 & 0.0004 & 0.0254 & 0.0236 \\ (0.5790) & (0.5770) & (0.5220) & (0.5510)\end{array}$

$\begin{array}{llll}-0.0006 & -0.0008 & 0.1775^{*} & 0.1841^{*}\end{array}$

$\begin{array}{lllll}0.6490) & (0.5650) & (0.0601) & (0.0515)\end{array}$

$\begin{array}{llll}0.0065 * * & 0.0068 * * & 0.1983 * & 0.2037 *\end{array}$

$\begin{array}{llll}(0.0151) & (0.0142) & (0.0755) & (0.0708)\end{array}$

$\begin{array}{llll}0.0004 & 0.0001 & 0.0462 & 0.059\end{array}$

$\begin{array}{llll}(0.6600) & (0.9070) & (0.5250) & (0.4250\end{array}$

$-0.0124 \quad-0.0121$

$(0.1580) \quad(0.1690)$

$0.0004-0.0001$

$0.0782 \quad 0.0674$

$(0.3600) \quad(0.4270)$

$-0.0604-0.0697$

$(0.6820) \quad(0.6400)$

$\begin{array}{ll}0.0683 & 0.0781 \\ (0.6350) & (0.5780)\end{array}$

$\begin{array}{llllll}-0.8426 & -0.8234 & 20.2238 & 18.242 & 0.1698 * * & 0.1752 * *\end{array}$

$\begin{array}{lllll}(0.5870) & (0.5970) & (0.5990) & (0.6340) & (0.0363)\end{array}$

No Yes $\quad$ No $\quad$ Yes No $\quad$ Yes

No No Yes Yes No No

$\begin{array}{llllll}619 & 619 & 619 & 619 & 634 & 634\end{array}$

$\begin{array}{llllll}0.09 & 0.10 & 0.14 & 0.15 & 0.07 & 0.09\end{array}$

Note: This table provides analysis of robustness checks on our previous results. First of all, see that we run the same analysis for both Likert scales (specifications 1 to 6 ) and Direction of Change measures (specifications 7 to 12). Second, we run different specifications for robustness checks. Specifications 1, 2, 7 and 8 include all level variables that seem relevant to outsourcing decisions and are available in our data set combined with industry fixed effects. Specifications 3, 4, 9 and 10 add to these specifications their square values and interaction effects between them (see the text for why the resulting second degree polinomial is a good proxy for initial levels in service outsourcing). Finally, specifications 5, 6, 11 and 12 introduce proxy variables for the level of outsourcing such as whether workers prepare their machines or do their maintenance, the percentage of laid off people due to retirement or other reasons, and whether recruiting and some HR functions are

P-values in robust standard errors in parentheses, ${ }^{* * *} \mathrm{p}<0.01,{ }^{* *} \mathrm{p}<0.05,{ }^{*} \mathrm{p}<0.1$. 